\title{
The Quest for Quality In Higher Education
}

BY RALPH E. ELLSWORTH

$\mathrm{T}$ HE IMPENDING Berlin crisis as it appears in July dampens our enthusiasm for long-range thinking or planning. Most of us, nevertheless, tend to hope that if we can just manage to keep them talking, neither of the two K's will get around to acting. There is hope in this theory. It has been used by us librarians for years and constitutes the basis for the healthy condition of the ALA and most of its divisions!

Now it is true that every recent commencement speaker, and every newly installed college or university president, has used the theme of "quality" or "excellence" in education, and the theme has become a cliche in the jargon of the day. We have reached the point where our talk has become a satisfactory substitute for really coming to grips with the problem.

Again, this indicates the appropriateness of the topic for an American Library Association meeting! Perhaps I should remind myself that this is a meeting of ACRL, not ALA, but in that case my gentle irony would be wasted!

Allow me now to talk about quality in higher education as I see the issues today.

First, the recent, widespread interest in quality has been generated from within universities, not from the expressed wishes of the citizenry, although there has been a small amount of that. The motives for this appear to be in some cases selfish and in some quite the opposite. When university presidents use the public's interest in quality as a de-
Dr. Ellsworth is Director of Libraries, University of Colorado. As incoming ACRL president, he delivered this speech to the general meeting of the Association of College and Research Libraries, at Cleveland July $12,1961$.

vice for browbeating state legislatures into making appropriations that enable the institutions to inaugurate programs for which they are unprepared, as we have seen in Illinois, Michigan, and elsewhere in the nation, I call this selfish. But when the pressures come from administrators who have conscientiously related their requests to their ability to produce, or to raise the quality level of the work of their institutions, one should applaud.

Second, I should like to mention several interesting ways in which the quest for quality reveals itself.

The decline in students' interest in professional training that students associate with preserving the status quosuch as law, medicine, and businessand their renewed interest in liberal education and in those professions that show promise of effecting social change - such as social service, clinical psychology, and teaching-is a trend I find heartening, not because the first group of professions is unimportant, but because the trend may convince these schools that they need to alter their approach to education.

The honors programs that are being created in great numbers are taking new 
forms and, it seems to me, having a real impact. They are helping to break up the long-standing monopoly of departmental regimentation and helping to emphasize independent study. I refer not to the well-established nineteenth century programs of upper divisional privileges given for outstanding achievement, but to new kinds of courses and teaching methods that permit students to formulate an attack on learning without regard to the old system of departmental requirements for the major.

The upgrading of public institutions of higher education-particularly the country-wide transition from the teachers' college to the university, and the state college to the university, painful though it may be to the old state university in each state-would seem to be in the public interest.

Although critics of higher education see signs of increasing conformity among our undergraduates, I see the opposite. The obvious decline in interest in intercollegiate football and in fraternities and sororities is an important sign, and so is the widespread interest in contemporary music and art and the "experimental" film. One can achieve real status among one's fellow students in many admirable ways quite apart from the fraternity system.

Various ways of freeing students from the constricting influences of the lecture system are gaining headway. The honors programs mentioned earlier (see files of The Independent Student) are one example. Popularity of the plan of making a year abroad an integral part of the four-year liberal arts course is another. Here and there one sees the results of truly enlighened programs of laboratory teaching in the high schools, even though, unfortunately, few colleges are prepared in their general educational level of courses to match the work of the best schools. And, of course, it is perfectly clear, although the idea is resisted with typical academic obstinancy, that tele- vision teaching, if properly conceived and used, can place the teaching of most of the elementary college courses on a fully independent basis. We have learned how to teach students to read well enough so that they can learn from books, and if we can do this with books I'm sure we can do it with television!

And now to a few observations on the obstacles in the path of our quest for quality.

\section{Right Kind of BoARd Members}

One of the most serious problems facing us is the difficulty we have in getting the right kind of people to serve on our boards of regents or trustees for statesupported universities. Too often the only people who will serve are the ones who are interested in getting the liberals (whom they call communists or "commysymps") off the faculties. It takes a courageous board these days to hold off the forces of bigotry, right wing extremism, and fear. It also takes courage to fight for the amount of money the universities need if they are to live up to their responsibilities. Have you ever heard of a regent or trustee whose good work was appreciated in a tangible way by the people of his state? I haven't.

Another obstacle is the way in which state legislatures are now exercising direct participation in the administration of universities. They do this by establishing super boards, by hiring their own educational experts and calling them chancellors, and by using the power to appropriate as the right to dictate policies. Their "experts" organize nationally and agree on the policies they will urge the various legislatures to follow and they develop so-called standards of performance against which requests for money are measured. The trouble with these is that they are based on the worship of the median, which means that excellence is equated with waste. California and Texas are the leading sinners in this respect. 
The nature and complexity of public university administration today determines the kind of man who takes the posts. There seems to be no place any more for the scholar-administrator who has an intimate understanding of the process of scholarship-including needs of libraries. There are exceptions, but fewer and fewer each year. Few sensitive men can stand the grueling pace and abuses that are an inevitable part of the work.

The unreasonable emphasis upon research and publication ${ }^{1}$ that characterizes so many of the larger public universities, does, in spite of pious claims for how research enriches teaching, have an adverse effect on teaching for the simple reason that faculty members in the university can't afford to spend too much time on good teaching unless this contributes to their own research. This is tied to the fact that in most subject areas there is so much easily available grant money for research. This seems to bring out everyone's latent talent for boondogling and may therefore have a serious effect on the desirable image of the professor. Unless you have a project going these days, you are reactionary. The amount of research grant money you bring into the department may become a measure of your worth. The old-fashioned idea of the humanistic scholar quietly at work on the ideas that interest him suffers in the atmosphere we are creating today in our universities.

The influence of the foundations that concern themselves with the teaching processes worries many of us. Some of it is obviously good, but when these funds are dispersed by men who never achieved real distinction in their subject areas, who have always shown a tendency to be on every bandwagon that comes along and who show an overwhelming love for the new, then the possibilities for harm

1 Earl T. McGrath, The Graduate School and the Decline of Liberal Education. (Published for the Institute of Higher Education [New York] Bureau of Publicaof Higher Education [New York] Bureau of Publica-
tions, Teachers College, Columbia University, p. 56 . are great indeed. We can be grateful that the Council on Library Resources has thus far been guided by a man whose judgment is good and who carries the respect of his colleagues.

Unwise external control of universities by national associations by means of accrediting and state licensing represents a serious weakness in higher education today. The professions of law, architecture, and education have been the most objectionable in recent years. Examples of good performance can be found in business, home economics, and library science.

\section{TEACHING vS. INDOCTRINATION}

Failure of colleges and universities to make clear to the American public the differences between teaching and indoctrination has left the public with unjustified fear that higher education is subversive in the fields of the social sciences.

The recent practice of diluting the value of the doctorate both directly through real dilution and indirectly through the establishment of special doctorates-doctor of education, of library science, of business, etc.-would seem to many a most serious weakness.

Slowness of our faculties to free themselves from the provincialism of a western civilization base for the humanities and the social sciences may prove to be our Achilles heel. The sciences have long since freed themselves of this provincialism, but the other parts of the universities have not. The other parts of the world resent the condescension that is implied.

The inability of higher education to meet the needs of a rapidly expanded population growth through a sensible economy of institutions is understandable, of course, but still a serious matter. Is it wise to let our campuses grow to enrollments of thirty thousand? Why are universities reluctant to allow these swollen enrollments to be taken care of by a 
larger number of rejuvenated or newly created universities? One wonders if they are not thinking mus avour their own self-interests than they are the needs of the public.

\section{Academic Librarians' Contributions}

In this, the third and last part of my paper, I propose to evaluate the contribution we academic librarians are making to higher education.

On the positive side, I think we librarians are more progressive in our thinking about education than are other people in universities. Most of us have had the benefit of a liberal education, and our outlook is broad and not so highly specialized.

We take seriously our responsibility for self-criticism and self-evaluation, and we have available excellent statistics as working tools.

We have a good national association to help us-both ALA and ACRL-and we have an enlightened foundation with money-the Council on Library Resources, Inc.- to help us solve our problems.

We are mostly humanistically inclined and we, therefore, view our problems in terms of their relevance to the needs of individuals.

On the negative side, we have limited our ability to attract into our ranks enough people who have a good background of subject knowledge and professional training because we have allowed our system of professional training to become a bottleneck. We place too much emphasis on the particular kind of professional training we have developed at a time when we should have been adapting our library schools to meet the needs of higher education. We are probably the least doctrinaire of all the professions in this respect, but that does not relieve us of the responsibility for acting more quickly. I will begin to rejoice when I see the library schools stop pretending that one kind of program meets the needs of all kinds of libraries. I thought Larry Powell of UCLA was going to be courageous enough to staff that school for the training of librarians for higher education, but I see that he, too, fell into the same old groove.

We also have some problems with our national associations. ACRL has not yet found a peaceful co-existence with ALA, nor have we resolved the problems of relationship between ACRL and the Association of Research Libraries.

In the new ALA structure, how are we to solve our problems when the associations based on activities (and this is an expression of the wishes of the membership, not the result of dark thoughts among ALA officials) glorify the type of activity? This organization inevitably makes it more difficult to keep activities in their proper relationships within the type of libraries.

This, it seems to me, is the problem we, as members of an association, must solve if we are to give to and take from our association the best that can be offered.

\section{Recruiting Material Available}

Librarians who counsel potential librarians or who work with counseling services will want copies of the recently revised list of sources of financial aid for study in the field of librianship, Fellowships, Scholarships, Grants-in-Aid, Loan Funds, and Other Assistance for Library Education in the United States and Canada (Chicago: American Library Association, Library Education Division, 1961). Up to ten copies are available from the Library Education Division without charge. Also available soon, for distribution, are the first two of the Demco recruiting brochures-the general pamphlet and the presentation of opportunities in library education today. 